\title{
The Politics of Wishful Thinking? Disentangling the Role of the Scholar-Scientist from that of the Public Intellectual in the Modern Academic Study of Religion ${ }^{1}$
}

\author{
DONALD WIEBE \\ University of Trinity College
}

\begin{abstract}
Although religion may well have relevance for various social, political, economic, cultural, and other related issues in society, I will argue here that this does not oblige the academic student of religion to become engaged with those matters. Indeed, to do so - not as a citizen but as a member of the academic guild which has responsibility to the field/discipline of Religious Studies and the modern research university at large - is to fuse and therefore confuse advocacy and scholarship. The task of the student of religion, qua scientist, is to seek to understand and to explain religion and religions, not to create the good society. I attempt to show here that with the infiltration of the ideal of the student of religion as public intellectual - whether as religious critic, critic of religion, or member of a new secular clerisy - the scientific agenda of seeking disinterested knowledge about religion and religions has been, and continues to be, eroded if not displaced.
\end{abstract}

A few years ago, Tim Jensen and Mikael Rothstein invited a number of scholars to contribute to a volume of essays on what a secular study of religion might look like. In the preface to that collection of essays they write: "We also asked the authors to touch upon the issue of the scholar of religion as 'a public intellectual'" because, as they put it, students of religion are not "isolated from general societal developments, and we therefore need to

\footnotetext{
${ }^{1}$ I wish to thank Luther H. Martin for his helpful comments on an earlier draft of the paper that was delivered at the $19^{\text {th }}$ Congress of the International Association for the History of Religions (IAHR), in Tokyo, March 26, 2005.
} 
discuss the position of the academic study of religion in the public sphere" (Jensen \& Rothstein 2000, 7-8). In my contribution to that book - Secular Theories of Religion: Current Perspectives (2000) - I noted with concern the "mounting pressure within the field to demonstrate [the] social and cultural relevance [of Religious Studies] and to incite the student of religion to assume the role of the 'public intellectual'" (Wiebe 2000a, 272). I acknowledged there that Religious Studies, like the sciences generally, may have relevance to public issues and concerns, but maintained that not only does this not oblige students of religion to become public intellectuals, but that in becoming public intellectuals they may well put the academic credibility of this discipline into question. The pressure for the academic student of religion qua scientist to contribute directly to broader moral and social policy issues in society continues and, as it seems to me, more professional and scholarly associations in support of scholarship in the field of Religious Studies have begun to change their focus of attention away from "pure" - i.e., areligious and apolitical - research. Religious and political goals, that is, are replacing the scientific agenda of seeking disinterested knowledge about religion and religions. Consequently I take this opportunity to explore and respond to the arguments in support of the idea of the student of religion as public intellectual which I think are either politically or religio-politically rather than cognitively motivated.

\section{Going Public or Not?}

Talk of the academic student of religion as public intellectual is a relatively recent phenomenon in the Religious Studies literature. ${ }^{3}$ To my knowledge,

\footnotetext{
${ }^{2}$ I follow Richard Neuhaus (1984) and Stephen Carter (1993) in my use of the notion of "the public square" to refer to the realm in which citizens work through the economic, social, political, cultural, and moral issues involved in their effort to create the good society. Jensen and Rothstein follow Habermas's usage of "the public sphere" to refer to these concerns that transcend the limited epistemic goals of scientists and scholars. Such epistemic goals, however, also emerge, so to speak, by virtue of conventions and procedures that allow for the verification and falsification of knowledge claims carried out in the public realm or public domain. It is important to keep this distinction between the public square and the public domain (sphere, realm) clear.

${ }^{3}$ There are numerous definitions and descriptions of public intellectuals in the literature on the role of intellect in society, not to mention the significant works given to theorizing intellect
} 
the explicit association of the notion of the public intellectual with the field of Religious Studies was first raised by William Dean - Professor of Religious Studies at Gustavus Adolphus College - in his book The Religious Critic in American Culture (1994) in which he identifies the student of religion as a public religious figure. Secular scholars in the field have also found the concept of the public intellectual congenial, if not essential to a proper understanding of Religious Studies. Three years after the publication of The Religious Critic in American Culture Russell McCutcheon, Professor in (and Chair of) the Department of Religious Studies at the University of Alabama, gave the topic greater visibility and, perhaps, notoriety in his essay "A Default of Critical Intelligence? The Scholar of Religion as Public Intellectual" (1997), published in the widely distributed Journal of the American Academy of Religion. For McCutcheon, however, the student of religion is not a religious critic but rather a critic of religion. In neither of these conceptions of the public intellectual is the student of religion concerned simply with pointing out the relevance that knowledge about religions and religion may have for policy issues in the public square. ${ }^{4}$ Indeed, as I will show, both views of the "religious studies public intellectual" see engagement in political or religiopolitical activity as an essential element in the academic study of religion. I will argue here, however, that (1) Dean's proposal uses the concept of the public intellectual to recycle a traditional religious perspective on the nature of the Religious Studies enterprise that threatens to dominate the field, and

and intellectuals. I shall not attempt here to review, let alone analyze, even a portion of that literature or the history of the associated debates. I wish only to point out that the authors I treat in this essay seem to use the concept of "the public intellectual" to refer to someone who addresses the general public on a broad range of economic, political, social, and cultural issues relevant to the well-being of society (or who seeks to become one whom the public consistently turns to for advice and wisdom on such issues or for the elaboration of a public philosophy in which such issues can be resolved). More particularly with respect to the authors considered here, they are academics (scientists, scholars) who wish to take on the role of a public intellectual precisely as academics. It is important to note here that I do not in this essay raise a problem with the notion of the public intellectual; it will become clear as I proceed that my concern is with the assumption on the part of many that the academic/scientist/scholar of religion can and ought to function as a public intellectual. Such a position, in my judgment, is as detrimental to the attempt to establish a scientific study of religion as is the attempt to incorporate a theological approach to religious phenomena in Religious Studies. This essay is an attempt to provide warrant for that judgment.

${ }^{4}$ See note two above. 
that (2) McCutcheon's notion of the Religious Studies scholar as "critic of religion" is no less ideological than Dean's concept of the student of religion as "religious critic," and therefore will be no less detrimental to a scientific conceptualization of the field of Religious Studies.

Public intellectuals for Dean are "critics" or "public thinkers" who, whether in analytic or constructive mode, concern themselves with the welfare of society. And for him, public intellectuals come in at least three varieties: social, cultural, and religious. Whereas "social critics" concern themselves with issues relating to political and material culture, and "culture critics" focus their attention on aesthetic and artistic culture, "religious critics," he argues, are public thinkers who believe that every nation ought to wrestle with the question of "[w] hat happens to a society whose implicit religious values are left to grow or decay in the darkness of inattention" (Dean 1994, ix), and who are committed to clarifying and establishing the religious identity of the nation. They are, therefore, public religious thinkers who analyze and reinterpret spiritual culture through discussion of ultimate meanings that allow for the construction of a holistic vision of society and a proper understanding of the common good. They are not, he maintains, narrowly traditional and institutional in their thinking, but rather are capable of being both "caretakers and critics of their culture's old spiritual conventions" and "principle devisers of their culture's new spiritual conventions" (p. xxi). By "conventions" Dean, following William McNeill's lead, means that religious critics will essentially be engaged in creating a sustainable public myth that can provide a society with a sense of the meaning of their nation. ${ }^{5}$

\footnotetext{
${ }^{5}$ William Dean here quite clearly asks the student of religion to take on the task of mythmaker in the sense that William H. McNeill (1986) presses on the academic historian. According to McNeill, the modern historian should reject the idolization of objectivity and attend to the care and repair of the myths that create and sustain society. A more recent, and more historically detailed account of this view is provided by Joseph Mali in his Mythistory: The Making of a Modern Historiography (2003). Mali "shows" here that the narratives that ground cultures and societies may not be factually accurate or true but that there is no need on that account to reject them as indicative of unjust or improper "authorizing practices". Although I find some of Mali's views on mythistory persuasive, his suggestion that historians must accept the task of rendering the historical mythological in order to evoke action - that is, to animate ethical
} 
In Dean's view, under pressure of the prestige of the sciences and secular scholarship in the modern research university, students of religion have over time become ivory tower scholars; "academic intellectuals" who are more preoccupied with the discipline of Religious Studies than with creating the groundwork for a "public philosophy" (Dean 1994, 167). ${ }^{6}$ In his judgment they are wedded to their disciplines and to the professionalism of academic institutions. ${ }^{7}$ As he puts it: "[M]ost academic intellectuals aim to alter an academic discipline, while public intellectuals aim to alter the public" (p. 157). To his mind, therefore, departments of Religious Studies, in which many religious experts find themselves, are directly responsible for the demise of the "religious critic" because their concern for scientific neutrality and for academic development leaves no room for attention to broader social and religious issues (pp. 25-26). ${ }^{8}$ Therefore, he writes, "professionalism [not religion] ... is the intruder on campuses, which once typically fostered the

and political beliefs about one's society or nation - is not one I find persuasive either in his, or McNeill's, account of mythistory. Donald E. Brown effectively argues a contrary position in his Hierarchy, History, and Human Nature: The Social Origins of Historical Consciousness (1988). He shows there that mythistories are tied to closed societies characterized by hereditary rather than open stratification which stifles historical consciousness and the development of sound historiography (Brown 1988, 10,17). According to him, then, mythmaking is simply productive of ideology in support of hierarchy and has, therefore, been detrimental to the social and historical sciences (p. 332). See also my critique of McNeill's position in my "History or Mythistory in the Study of Religion? The Problem of Demarcation" (Wiebe 1989).

${ }^{6}$ In the preface Dean also claims that the task of the student of religion ought to involve creating "theories of the meaning of American public life or of the nation" (Dean 1994, xviii) and he sees this as especially important in light of the fact that the myth of American exceptionalism has become wholly unconvincing. That myth, he claims, had once kept alive a spiritual culture in America and its loss of credibility disabled public intellectuals and pushed them into academic careers. As he puts it: "The academic career gave structure and meaning to the intellectuals, even if it made no claims to fill the newly voided spiritual culture" (p. 19).

${ }^{7}$ Dean here simply ignores the benefits of disciplinarity - of what Robert McCaughey (1984) calls the "academic enclosure of learning" - to scholarship. Such "enclosure" helps to ensure that plausibility, factual correctness, and testability in hypotheses and theories emerge rather than merely the expression of opinion and unsubstantiated generalization. Academic enclosure (often referred to in derogatory tones as academicization) also means that metaphysical claims and matters of meaning and value that cannot be "handled" in the same way are relegated to other venues for discussion and debate.

${ }^{8}$ As will become clear below, Dean is quite right to assume that opposition to the public intellectual in elaborating the notion of Religious Studies as an academic discipline within the modern research university must necessarily exclude a theological approach to understanding religion because the theologian, like the public intellectual, is concerned not only with 
development of citizens, even religiously sophisticated citizens" (Dean 1994, 160). Thus, in his estimation, students of religion have become "ineffectual intellectuals" (p. 172). ${ }^{9}$

Nevertheless, Dean maintains that it is the scholar of religion who is best able to undertake the task of the "religious critic"; that the scholar of religion is by nature, so to speak, a public intellectual whose task is to rescue society. Religious Studies scholars and theologians, that is, are those whose training has provided them with the knowledge and skills to become caretakers of their culture's old spiritual conventions and devisers of new spiritual conventions when they are needed. But given the dangers of professionalism in the university context (that is, the narrow academicization or specialization of the field), ${ }^{10}$ Dean advises the religious critics to affiliate themselves with third sector institutions other than the universities - such as churches, social action agencies, gender- and race-based rights groups, foundations and charitable organizations, among others - because these institutions are more imaginative and creative in the attention they pay to cultural matters, and they tend to pertain more directly to questions of the

\footnotetext{
knowledge but also with meaning and value. Both the theologian and the public intellectual are concerned with the transformation of the self and society and not merely with knowledge about the self and society; both see knowledge on the one hand, and meaning and value on the other, as inseparable concerns.

${ }^{9}$ Another possible, and in my judgment more plausible, conclusion is not that they are "ineffectual intellectuals" but that they are not public intellectuals at all but rather scientists/scholars/ academics whose attention is directed to quite different (i.e. cognitive) ends.

${ }^{10}$ The professionalism of which Dean speaks is precisely what transformed the early American college into the modern research university. That such professionalism was the "intruder" on the nineteenth-century college campus (substituting cognitive and technical goals for traditional, religiously inspired aims) cannot be denied. But neither can one ignore the nature of the new institutions that emerged from that evolution. To think it possible to roll back that development without serious detriment to the modern university, or to society at large, is surprising. This is almost tantamount to a retreat to a mythopoetic mentality of the kind described by Gellner in his essay "The Savage and the Modern Mind" (1973) that is governed by the use of idiosyncratic norms that are dedicated to providing a vision of moral life and practice and therefore are both cognitive and moral at the same time. The modern mentality, Gellner argues, differentiates the cognitive base-line that makes possible a scientific understanding of the world from those that govern the moral and social order. To reject the professionalism of the university because it does not allow the scholar/scientist to construct a vision of society and the world is also to reject science. Using Peter Munz's terminology (1985), it is to attempt to turn the clock back to a time when belief was essentially catchismic (i.e., belief that creates a bond that holds members of a group together) rather than purely cognitive (i.e., providing knowledge about states of affairs in the world).
} 
public good than do the norms of the university, let alone the norms of the first and second sectors (government and the market) of society.

Despite this advice, Dean maintains that the academic institution offers the most obvious context for the work of the religious critic. Indeed, he even acknowledges that some academics have refused to submit to the academicization and professionalization of the university (a gross understatement in my opinion) and, in light of postmodernism's attack on disciplinary scholarship, he suggests that it may now be time to insist "that the academy be made once again congenial to the public intellectual, including the religious critic" (Dean 1994, 157). ${ }^{11}$ Dean's reliance here upon the "arguments" of postmoderns regarding disciplined research, however, is problematic, to say the least, ${ }^{12}$ and his suggestion that the academy is

\footnotetext{
${ }^{11}$ Dean notes, that is, that some academics have refused to submit to the professional, academic agenda of the college, university, and seminary, and that these venues seem to offer the obvious contexts for the work of the religious critic. And in light of postructuralism's attack on the professionalism of disciplinary scholarship - although it has not yet succeeded in fully undermining that professionalism - Dean suggests that it may soon be time to insist "that the academy be made once again congenial to the public intellectual, including the religious critic" (Dean 1994, 157). There are some interesting parallels to Dean's attempt to return a form of theology to the academy in Jack Miles's (1999) concern over the liberal arts being squeezed out of the university curriculum. Whereas Dean recommends that "religious critics" make use of third-sector institutional venues other than the universities (although not necessarily giving up their university professorships) Miles points out that the college and university teachers in the humanities, who in his opinion carry American culture, are being deprofessionalized and proletarianized by being forced into part-time positions "by academe's progressive disinvestment in the liberal arts" (Miles 1999, 305-306). The humanities, he claims, are being outsourced and the academics involved are being "displaced into the general labor market" (p. 306). Such "academics" are, then, allied to other institutions such as libraries, museums, academic computing positions, and the like, which means that the off-campus humanists, as he calls them, become the default carriers of the liberal arts, and therefore, of American culture in the same way that "off-campus" religious critics are the carriers of theological concerns. In Miles's assessment, however, these "scholars" represent a "more avocational style of liberal arts research and publication" and he maintains that they are, therefore, more "intellectuals" than "academics" because in the process they become generalists who address a broader range of people than other academic specialists. (Miles entertains the thought that such generalists may also be referred to as "public academics", although that kind of academic, he suggests, would probably be a transitional type: "an academic moonlighting or auditioning as an intellectual" [p. 305].) Like Dean (with respect to the theologian) Miles regrets the academicization of the humanities and believes that the "humane tradition" will slide into further decline if it is left entirely to the off-campus intellectuals.

${ }^{12}$ Claims by postmodernists that the objectives of the modern research university have already been shown to be incoherent are, I think, without merit. As Richard Wolin (2004) has put it: "Today the postmodern juggernaut seems to have run aground. Outside of the parochial climate of contemporary academe, its program of a 'farewell to reason' failed to take root"
} 
not congenial to the religious critic is simply descriptively (empirically) wrong. A more objective view of the place of Religious Studies in the modern American college and university, I will argue, does not reveal what Dean sees as a "degenerative" change in the religious character of the study of religion in these institutions. Even a cursory examination of the American Academy of Religion (AAR) - the primary professional association in the field of Religious Studies that represents about 10,000 college and university teachers of religion (and about 1,500 departments of religion) in the U.S. - will show religion and the religious critic to play a dominant role in the teaching of religion in America.

\section{The Role of Religious Studies in Public Life}

It is true that by the mid-1950s and early 1960s the parochial religious objectives of the National Association of Biblical Instructors (NABI) - out of which the AAR came into existence - were under review because of changes in the academy and because of the increasing diversity of religious

(Wolin 2004, xii). John H. Zammito's critical review of postmodern theory and its philosophic attacks on positivism and scientific knowledge since the 1950s found in his A Nice Derangement of Epistemes: Post-Positivism in the Study of Science from Quine to Latour (2004) comes to the same conclusion. His history reconstructs what he calls the three hyperbolic dogmas of "antiempiricism" that have dominated postmodern theory throughout this period, namely, theory-ladenness, underdetermination, and incommensurability, and he shows that "[n]one is justified in the radical form which alone empowers the extravagances of postmodernism" (Zammito 2004, 271). Consequently, he claims, they do not justify the denigration of science (and empirical knowledge) that postmodernists have heaped upon it; and "real philosophers," he insists, "have increasingly taken a deflationary view of their authority over the empirical disciplines" (p. 3). Although he does not deny that the postmodern theorists have something to teach us, he nevertheless contends "that it is time to take up a more moderate [deflated] historicism" (p.5) and claims that after the extravagant postmodern claims are dispelled, what remains will be "fully assimilable into - not preemptive of - empirical inquiry" (p. 2). His concluding paragraph is worth quoting in full: "There has been a derangement of epistemes. Philosophy of science pursued 'semantic ascent' into a philosophy of language so 'holistic' as to deny determinate purchase on the world of which we speak. History and sociology of science has become so 'reflexive' that it has plunged 'all the way down' into the abîme of an almost absolute skepticism. In that light, my fears are for empirical inquiry not in the natural sciences, whose practitioners brush all this off as impertinence, but in the human sciences. Hyperbolic 'theory' threatens especially the prospect for learning anything from others that we did not already presume. It is time for a hard reckoning, for a rigorous deflation. Willard Quine put it with uncharacteristic bluntness: 'To disavow the very core of common sense, to require evidence for that which both the physicist and the man in the street accept as platitudinous, is no laudable perfectionism; it is a pompous confusion"' (p. 275). 
views among the Association's members, and especially so with respect to religious pluralism. It is also true that many American students of religion believed that the American Academy of Religion (AAR) should be concerned with bringing academic respectability to the Religious Studies enterprise and therefore rejected the notion of the student of religion as religious critic (and, consequently, left no room for a religious approach to the study of religion). Thus, whereas the National Association of Biblical Instructors (NABI) was dedicated to "increas[ing] the spirit of fellowship among themselves and to [assisting in the] practical development of the religious life of students"13 (and the role of religion in the life of the nation), the AAR appeared to be committed to the establishment of Religious Studies as a purely scientific discipline. In late 1961 a NABI Self-Study Committee recommended a change of orientation and a change of name for the organization which, it was hoped, would give the study of religion in colleges and universities in the United States a broader cultural scope and appeal, and greater academic respectability than it had been accorded in the past. Thus, as Clyde Holbrook put it in his 1963 NABI presidential address, the changes were intended to make the new American Academy of Religion "a society which gives high prominence in the academic world generally to the serious importance attached to religion as a scholarly enterprise" (Holbrook 1964, 103). And in 1970 Claude Welch, the seventh president of the new AAR, announced that " $\mathrm{t}$ ] he [scholarly/scientific] legitimacy of the organized study of religions in colleges and universities has now been established, and this is so widely recognized that it need no longer be a subject of anxiety" (Welch 1971, 6). It is clear that Welch meant by this that the new Academy was now self-consciously committed to a scholarly-scientific agenda rather than a religio-theological one, for as he puts it: "The battle for recognition of religion as an appropriate and desirable area of organized study in college and university ... has been largely won [and] in this sense, the period of emergence of a discipline of '[R]eligious [S]tudies' (as distinct from theology) is coming to an end" (p. 6).

\footnotetext{
${ }^{13}$ See R. V. Smith et al. 1964, 200.
} 
The "transformation" of the NABI into the AAR, as I have just acknowledged, did in fact move the academic study of religion beyond the hegemonic liberal Protestant framework that had characterized the NABI, but it did not, as I will show, transform the ultimate goals of the majority of scholars who comprised the new AAR. There were few, if any, members of the new AAR who were concerned exclusively, or even primarily, with the establishment of Religious Studies as a scientifically respectable discipline, and even fewer college and university departments of Religious Studies devoted primarily to scientific objectives. ${ }^{14}$ The "new" American Academy of Religion that succeeded the NABI, I will argue, clearly still conceived of the Religious Studies enterprise as being as much directed toward the religio-moral needs of society (on and beyond the university campus) as it was toward cognitive ends, and was, therefore, in some sense still directed towards matters of "ultimate concern" (although in a non-supernaturalist, or at least modified supernaturalist, guise). Welch, in my judgment, therefore, was overly optimistic in his estimate of developments in the early years of the Academy, and Dean was overly pessimistic in his. Furthermore, even if the Academy had moved the study of religion in a non-confessional, scientific, direction, it did not take long for it to fall back "into the arms of confessional interests," as Welch had feared it might (1971, 12), which clearly undermines Dean's claims about the professionalization of the study of religion in America. ${ }^{15}$

The AAR I maintain, then, effectively returned to its prophetic NABI roots with its primary commitment to religious scholarship and ministry, rather than to the scientific study of religion, ${ }^{16}$ and, therefore, resembles precisely the kind of study of religion called for by Dean. This is clearly indicated,

\footnotetext{
${ }^{14}$ I provide a fuller statement on this matter in my book on The Politics of Religious Studies: The Continuing Conflict with Theology in the University (Wiebe 1998); see especially chapters 5 , 6,14 , and 15 .

${ }^{15}$ In addition the essays mentioned in note 7 above, see also my "American Influence on the Shape of Things to Come: Religious Studies in the Twenty-First Century" (Wiebe 2000b) and "Religion Thick and Thin: On the Development of 'Religious Studies' in the American University" (Wiebe 2001).

${ }^{16}$ It should be noted here that "NABI" - the acronym of The National Association of Biblical Instructors - designates "prophet" in Hebrew; the name of the association was clearly chosen to provide indication of the primarily religious goals of the Association.
} 
for example, in Robert Michaelson's 1972 presidential address entitled "The Engaged Observer: Portrait of a Professor of Religion", in which he argues for an integration of the aims of the religious devotee (theology) with that of the academic student of religion (science) which seems in essence to describe the religious public intellectual as conceived by William Dean. Michaelson argues that these "new developments" (that is, the organizational move from NABI to AAR) condemned the professor of religion to a schizophrenic existence. Even though most of them had been trained in seminaries and still concerned themselves with existential issues, he maintains that they now had to prove themselves "worthy as scholar[s], teacher[s], and colleague[s]" with respect to the notion of "scholarly objectivity in the rigorous pursuit of truth" (Michaelson 1972, 420). And this in turn, he insists, required of them the cultivation of the virtues of scepticism, quantification, iconoclasm, etc., patterns of thought that had created cultured despisers of religion of so many in the university. Michaelson, however, also points out (claims) that interest in detached, objective, scientific scholarship fell out of fashion in the late 1960s and early 1970s, and that student interest in religion - of a more primal sort rather than in traditional institutionalized religions - created a religious revival on college and university campuses that called for subjectivity, commitment, and involvement (p. 421). This lack of interest in professionalized religious studies scholarship also called into existence new possibilities and responsibilities for the professor, including that of helping students (and society) to achieve wholeness, and to helping the university bring some kind of integration to its obviously fragmented curriculum. The "professor of religion", therefore, was to be celebrant, midwife, and guru rather than, (or, in some instances, in addition to) scholar and scientist (p. 421). Michaelson recognizes that this change may simply have given rise to a new product which he calls "classroom religion" (p. 422), involving the displacement of the cultured despisers of religion by the religious despisers of culture, yet he insists that there is something of value in both these positions. Indeed, he maintains that this paradox cannot be avoided. "The professor of religion", he writes, "is caught up in questions of professorial 
position and existential stance, and the two cannot be separated. That much the age of involvement has taught us" (Michaelson 1972, 423). ${ }^{17}$

Although Michaelson does not speak of the "religious critic" in Dean's sense of the term, it is clear that his understanding of the proper role of the study of religion on the university campus (like that of the former members of the NABI) is wholly in sympathy with Dean's criticism of the professionalization of the field - with the view that Religious Studies is an essentially scientific enterprise directed towards cognitive goals. Like Dean, he also understands the study of religion to catapult the scholar beyond purely cognitive goals to concerns for the welfare and development of both the individual and society, and in this he, in effect, carries forward (resurrects) the religious (theological) agenda of the NABI. Clearly, therefore, the notion of the student of religion as engaged in religious and religio-political agendas pre-dates, although it also overlaps, Dean's use of the notion of the student of religion as "religious critic" and "public intellectual".

I have shown elsewhere that it is Michaelson's view of the work of the Academy and not that of Welch that has come to dominate the American

\footnotetext{
${ }^{17}$ This development, it should be pointed out, was not peculiar to the U.S.A. The Canadian scholar Joseph McLelland of McGill University drew a similar conclusion about the true nature of the study of religion in his 1972 essay "The Teacher of Religion: Professor or Guru?"; the academic student of religion, he insisted, must be both professor and guru (McLelland 1972, 230). McLelland, however, argues his claim on what he thinks are sound philosophical grounds. He maintains that the adoption of a strictly (objective) phenomenological approach to the study of religion would be an unjustifiable adoption of a metaphysically reductionist position with respect to religion in that in denying "the referential status of religious behaviour and statements" (p. 231) it assumes an ontological stance without supporting argument. (McLelland, however, fails here to recognize the difference between metaphysical and methodological atheism in the study of religion.) As he (partisanly) puts it: "If by 'phenomenology' ... we intend some cult of objectivity that denies the humanity of both subject and object, it would seem an inappropriate discipline for the study of religion" (p. 232), for neither the professor nor the student, he claims, can deny that personal commitment to a "root metaphor" orients her/his life and necessarily involves him/her in political, social, and other metaphysical (theological) commitments (pp. 230-231). Thus, he writes, he doubts "that the introduction of the term 'scientific' as a qualifier of the discipline called 'study of religion' has proved helpful" (p. 229). Students will raise theological issues and as long as those issues are not "dictated by partisan dogmatics" they must be responded to by the professor, with "open commitment"; a commitment that "does not deny his [her] supreme value-centre ... but which supplies brackets when necessary, and which maintains an openness to persons and to truth" (p. 232). Such commitment cannot exist without competence and competence without such commitment, he insists, results in deception and deceit (p. 234).
} 
approach to the study of religion, and I will not recapitulate that argument here. ${ }^{18}$ I will, however, look briefly at Carl A. Raschke's essay on "Religious Studies and the Default of Critical Intelligence" (1986) because he adds a new twist to the argument for a public role for religion and the student of religion - although he does not directly invoke the notion of the "religious critic" or "public intellectual" - that will have an impact on later elaborations of this theme. Raschke accepts the claim that the academic study of religion under the banner of the AAR attained a professional dignity not accorded the NABI but nevertheless, like Michaelson, thought this was bought at the cost of losing "the autonomous constructs of religious inquiry" (p. 132) and the moral and cultural influence of religion on America. The desire for academic credibility and the espousal of religious pluralism, he believed, dissolved the fundamental impulse behind the study of religion, namely, the rational theoretical inquiry into ultimate principles by which the universe is constituted and governed (Raschke 1986, 133). And in his judgment this rejection of a type of theological approach to the study of religion constitutes "a deliberate default of our critical intelligence" (p. 135) because it inhibits "ontological probing and analysis" (p. 135) which alone makes possible normative distinctions and normative guidance in the study of religion. To his mind, therefore, the academicization of the study of religion in the American context constitutes a "reverse Tertullianism" because learning has effectively replaced religion in the order of values in the university setting.

It is not altogether clear that Raschke's battle is with the academy in the sense of the university or the Academy as in the AAR, or, as is more likely, both. At the very least he assumes - but does not demonstrate - that the fundamental religious impulse that gave rise to the desire for an intellectual understanding of the faith (religion) had been subordinated to the desire for intellectual respectability over religious fidelity. Thus, whereas Welch thought that the academic study of religion had been emancipated from a religious agenda but feared that it might fall back into the arms of

\footnotetext{
${ }^{18}$ See notes 14 and 15 above.
} 
confessionalism, Raschke feared that the "academic" autonomy the field of Religious Studies sought was destroying the religious impulse that brought the study of religion (faith) into existence in the university system in America in the first place and was also, therefore, undermining the raison d'être of the enterprise. Once again, however, Welch's fears were wholly justified given the history of the study of religion in the U.S. whereas Raschke's anxiety was entirely unfounded. The thorough embeddedness of the notion of the "guru/public intellectual" in the thought of the leadership of the AAR makes that crystal clear. With the exception of William A. Clebsch's (1981) 1980 AAR presidential address which, like Welch's a decade earlier, raises concern over the subordination of the objective, scientific (scholarly) impulse to a religious agenda, the presidential addresses have either focussed on specific religious and humanistic themes or have argued the importance of the re-integration of theology with Religious Studies in the hope of establishing the scholars in this field as a new clerisy for modern society. ${ }^{19}$ Furthermore, in the late 1980s and early 1990s one begins to see the rhetoric of postmodernism gain strength in the cases being made on behalf of a religio-political agenda for the discipline, with a concomitant attack on scholarly-scientific professionalism in the field as a reigning ideology. The constant refrain from the elected leaders of the AAR, therefore, is that scholars of religion ought to defend religion and promote its value (as well as that of the [proper] study of religion) to nation and society - that is, in Dean's sense, that scholars of religion should be public intellectuals who are "religious critics".

\section{The McCutcheon Argument}

In "A Default of Critical Intelligence? The Scholar of Religion as Public Intellectual" (1997) Russell T. McCutcheon presents what appears to be a radically different argument in support of the student of religion as public intellectual. Although McCutcheon refers to Dean's The Religious Critic in

\footnotetext{
${ }^{19}$ By "clerisy" I mean to refer to a group (usually of humanists) who consider themselves capable of taking on the social and moral functions once filled in society by the clergy and religious; their aim is to protect modern secular society from a complete loss of the transcendent and, consequently, from social chaos, if not total social collapse.
} 
American Culture, he develops his argument by way of contrast to Carl Raschke's claim that in seeking scientific credibility the academic student of religion gave up the possibility of exerting religious influence on the world. For McCutcheon, the "default in critical intelligence" in Religious Studies is to be found not only in wanting to influence the world religiously, but also in not wanting to influence the world at all. His stance here is not altogether clear, however, because it seems to confuse substantive with methodological issues, and at times involves accepting mutually inconsistent positions. And his failure, moreover, to clarify his understanding of the notion of the public intellectual simply adds to that confusion. Nevertheless, I believe that the account of his position that follows sets out the essential elements of his proposal and its weaknesses.

McCutcheon grounds his critique of the contemporary academic study of religion on two "observations": that most students of religion in the academy believe that the study of religion can provide humankind with otherworldly insights of great personal and social import (McCutcheon 1997, 447) and that most of the students of religion committed to it as a scientific undertaking are content with simply "reporting" religion as it sees itself (p. 449). Although McCutcheon agrees that the academic study of religion ought to be scientific in character, he rejects the assumption that science can achieve transcendent truth and he therefore denies that the task of the student of religion is to bring such truth to bear on society. Nevertheless, like Michaelson and Dean, and many other religiously orientated students of religion, McCutcheon also rejects purely philological, historical, phenomenological, or other scientific approaches to the study of religion. For him, the secular scientific student of religion who is socially disengaged also shows a default of critical intelligence. It is interesting in this regard to note that McCutcheon does not criticize Raschke for his concern that religiously orientated students in the field will lose their influence on society if they espouse a purely scientific methodology for the discipline; his concern here is rather over the religious character of the influence such scholars seek. I think McCutcheon's argument on this point confused, but it seems to me that it 
amounts to the claim that scientific students of religion who remain socially disengaged, and who do not become critics of religion and its influence on society, are by default religion's caretakers (i.e., that they passively support a role for religious narrative in society) and are, therefore, indistinguishable from the religious students of religion praised by Michaelson and Raschke. However, unlike his counterparts in the field, McCutcheon, it appears, seeks no conventionalist alternative narrative to guide society in place of the traditional theologies he rejects; he claims, that is, that the religious scholar's task is not that of providing society with a public philosophy for the proper ordering of social and political life. Nevertheless, according to McCutcheon, the genuine academic study of religion requires the student of religion to be "explicitly engaged in the ongoing project of the critique [of religion]" (McCutcheon 1997, 453); the "default of critical intelligence" in the work of the neutral or objective modern student of religion is to be found, therefore, in the scholar's refusal to move beyond the appreciation of religion (as with traditional scholars in the field who limit themselves to a re-presentation of it) and the refusal to subject religion (and the so-called objective study of religion) to critical theorizing (p. 452). Thus, as McCutcheon puts it, the student of religion must be wary of merely reproducing the authority of religion in so-called neutral descriptive scholarly accounts ("translations" [p. 452]) of it. Borrowing from Terry Eagleton (1992), he insists that instead the scholar of religion must "transgress discursive frontiers" (McCutcheon 1997, 451), and be "involved in the action of resistance" (p. 452), but he claims that this does not involve becoming engaged in "politics" and the reconstruction of society. To put it simply, McCutcheon seems to believe that if, as a student of religion, one "reveals" the falsehood of religion and shows that it is not therefore a solid foundation on which to establish society, as a student of religion one has fulfilled one's duties as a public intellectual.

Unfortunately, matters are not quite this simple; it seems that critical theorizing - the transgressing of discursive frontiers - does not, as McCutcheon suggests, simply amount to disclosing the role religion has played in society in the past. Critical theorizing involves explaining why a social institution 
functions as it does (p. 454), but must go beyond simply providing a scientific, causal explanation of such institutions. Drawing on Bruce Lincoln (1996), McCutcheon maintains that the student of religion must also be a "critical rhetor" - a "scholar of social authorizing practices" - which amounts both to uncovering disguised mechanisms that lie behind such institutions (McCutcheon 1997, 459) (something modern social scientific scholars undertake as a matter of course) and to challenging the social power structures that underlie those mechanisms. But, contrary to his claim that Religious Studies does not become engaged in politics, he admits that this amounts to a political act (p. 460) in that the criticism (critique) amounts to countering the effects of those scholars of religion who presume the truth of religion (p. 456) (not something modern religion scholars see as part of their scientific agenda). ${ }^{20}$ This kind of critical study of religion is a political act, he (paradoxically) insists, because it finally reveals that religion in itself is not an explanation of anything, and this demands (though McCutcheon does not show why) that the student of religion must work to undermine the influence of religious thought on society (p. 456). ${ }^{21}$ Thus he writes, “ $[t]$ here exists a default of critical intelligence among scholars of religion, scholars who proclaim their apoliticism and in the very same breath descriptively reproduce the authorized 'sacred histories'"' (p. 460). Those scholars, he maintains, are, wittingly or otherwise, caught up in a politics of nostalgia because they are concerned with the recovery of past values which, they hope, will ignite a resurgence of religion in public life.

\footnotetext{
${ }^{20}$ As Kurt Rudolph (2000) points out, "when it comes to firm religious convictions, work in the study of religions has 'ideological-critical' consequences" because in "one way or another, knowledge of the history of religions inevitably alters the religious consciousness of the researched and of the perceptive readers of his or her work" (p. 239). In this he is, of course, in agreement with McCutcheon; he does not, however, believe this requires the student of religion to demand that religious devotees give up their beliefs or even of working toward relieving them of such beliefs. Indeed, quite to the contrary, he counsels the student of religion to tolerate others' beliefs.

${ }^{21}$ I find McCutcheon's focus on Stephen Carter at this point in his argument a little strange given that Carter is not a student of religion. I have, nevertheless, read Carter's The Culture of Disbelief (1993) and his God's Name in Vain (2001) to try to understand McCutcheon's concern. Although I have reservations about some aspects of Carter's philosophy of religion (and particularly so in the latter volume) and am left unpersuaded about his religious claims, I have no great problem with Carter's concern that religious belief and commitment be taken seriously
} 
This conclusion, however, is a non-sequitur; McCutcheon does not show that apolitical scientific scholars actually secretly seek a resurgence of religion or, in providing an objective description of religion, literally reproduce the realities about which they write. Not following up a descriptive account of religion with a critique of the "authorizing practices" embedded in the illusion McCutcheon takes religion to be, is not automatically to give silent assent to it or to support it. Furthermore, McCutcheon himself claims to espouse a form of apoliticism even though his discourse presumes an alternative authorizing narrative (given his insistence that societies do not exist without authorizing narratives). ${ }^{22}$ He simply refuses to elaborate the implicit

in the public square (on which, see note 23 below). Carter does not seek the establishment of religion, nor does he seek secular power for religion. He does, however, expect that the world view of religious persons be treated respectfully, as are other world views, in the discussion of the common good in society. Carter's views on the role religions play, or might play, in limiting the prospects of majoritarian tyranny in a secular culture are also interesting and worth consideration. I have a far greater anxiety about the kind of argument for the role of theology in public life that involves university departments of Religious Studies such as that which Linell E. Cady presents in her Religion, Theology, and American Public Life (1993). Like Stephen Carter (and William Dean) Cady believes the public realm in America is in need of reconception, and she is convinced that, given the limitations of science with respect to the discernment of meaning in the world, religious interpretation remains a viable resource for that task, so long as it does not directly contradict our scientific knowledge (Cady 1993, 101). As she puts it: "One of theology's more important tasks today is in keeping alive the tradition of attending to the 'metaphysical-moral' visions by which people live" (p. 90). However, unlike Carter, but very much like William Dean, Cady argues not only that religion be taken seriously in the public square, but that the religion that is to be taken seriously ought to be formulated by theologians in the context of the modern university. Consequently Cady argues for a role for theology in the modern university curriculum as part of the Religious Studies enterprise already established in that context. She argues that Religious Studies ought not to be confined simply to objective, descriptive studies of religions (a position, it might be noted, not much different from that proposed by McCutcheon) but should concern itself with the issues of meaning (ends) and values as well as of knowledge (a position in which she differs from McCutcheon only in that the values she espouses are religious rather than secular). Religious Studies (and theology which she thinks ought to be an aspect of it), that is, is "to engage in public exploration about the nature of the good life for the individual and society" (p. 166). But this clearly requires a rejection of the notion of Religious Studies as a modern disciplinary undertaking "subject to the constraints of the reigning university ethos - that is, dominated by the Enlightenment model of rationality" (p. 166). June O'Connor presents a similar argument in her critique of McCutcheon entitled "The Scholar of Religion as Public Intellectual: Expanding Critical Intelligence" (1998) though McCutcheon (1998) remains unpersuaded by her argument. On this matter see also the essays in Linell E. Cady and Delwin Brown (eds) Religious Studies, Theology, and the University: Conflicting Maps, Changing Terrain (2002).

${ }^{22} \mathrm{McC}$ utcheon does not elaborate on the "authorizing narrative" that will have to replace the religio-theological narrative he wishes to remove; nor does he spell out how this would affect 
secular narrative that for him must not only replace religious narrative but presume its demise. This suggests to me that McCutcheon is caught up in a politics of wishful thinking.

McCutcheon confuses the picture of the Religious Studies public intellectual further by emphasizing that it is objective, critical scholarship that is responsible for the discovery of the real (natural, rather than supernatural) mechanisms that account for the origin and function of religion and he suggests that that discovery, in and of itself, will transform society. If that were in fact the case, however, there would be no difference between the scientific student of religion and McCutcheon's ideal of the academic student of religion as a public intellectual and nothing further would need to be said. McCutcheon, that is, insists that a true (naturalistic, scientific) account of the emergence and development of religion will undermine the supposed supernatural origins of religion and therefore show the detached and dispassionate scholar of religion to be, automatically it seems, an "oppositional scholar". But that is not where McCutcheon leaves the matter. He claims, that is, that being a "critic of religion" does not mean simply providing an apolitical, critical understanding of religion in the sense of a scientific explanation of it. He uses "critical" here in the broader, European, sense of the word rather than in the sense of the use of formal methods for testing scientific hypotheses and propositional claims. Thus, for him, contrary to what has just been said, being a critic of religion does not simply mean providing a critical or scientific understanding of it. "Criticism" for his "critic of religion" is not concerned with matters epistemological but rather relates to, or involves, reflection on matters cultural and social; as he puts it, it involves "oppositional thinking" in the sense of "unveiling" and "debunking" the claims made by religion so as to allow other narratives "social authorizing" space. Although both "critical thought" and "critical theory" may disclose the real foundations and motive forces of religions and

the functioning of the discipline in the university classroom (or in scholarly research). It seems, then, that McCutcheon expects positive political results to flow automatically from the adoption of methodological atheism as the default assumption of the scientific study of religion. I think one might with justification dub this a "politics of wishful thinking". 
religion, for McCutcheon the primary responsibility of the Religious Studies scholar as public intellectual, it appears, is to liberate persons bound by what he considers religious illusion. The Religious Studies scholar, therefore, is more than a merely dispassionate scholar or scientist, for $\mathrm{s} /$ he must aim at emancipating humankind (one presumes) from conditions that constrain it; it is not enough merely to describe and/or explain the (religious) world as it is. McCutcheon's scholar as public intellectual, therefore, is much like Dean's; s/he differs only in holding (implicitly, it seems) a non-religious (and implicit) ideology rather than a religious one.

McCutcheon does not spell out clearly what this task of being more than a mere dispassionate scholar, but less than a politician, amounts to. Moreover, his elaborations of what being a Religious Studies public intellectual amounts to are more convoluted than intricate, and possibly even deeply confused. ${ }^{23}$ As I have already pointed out, he denies that his public intellectual involves taking on the role of the politician (McCutcheon 1997, 457), yet maintains that demonstrating that religion is a social construction is itself a public political act (p. 460), because, he says, in doing so, the scholar becomes a "critical rhetor" or "oppositional scholar" with "something important to say on the public stage about such issues as the place of religious intuition, insight, and commitment in the public domain" (p. 462). But such a claim confuses college and university campuses and related institutions with the public square. The scientist-scholar may indeed take an interest in the public square, but not, I suggest, as a participant in it; rather s/he will, qua scholar, limit herself/himself to descriptive and explanatory accounts of how religious intuition, insight, and commitment actually play out in various societies but without normative comment about these matters in the public domain. McCutcheon's view of the Religious Studies scholar as a "critical rhetor" who is necessarily engaged in normative comment on religion goes far beyond the bounds of what the student of religion qua scholar-scientist can say on the basis of a "critical analysis" of religion; that will be limited

\footnotetext{
${ }^{23}$ In this criticism I have some sympathy for Paul J. Griffiths in his response to McCutcheon's essay in JAAR (1998), although I think Griffiths simply refuses to spend any time trying to figure out what McCutcheon's essential concern really is.
} 
to a careful historical description of religions, controlled methods of critical testing of hypotheses and theories about their emergence and development, and a careful delineation of conclusions in the light of the evidence, analysis, and argument. His "critical rhetors" and "oppositional thinkers", however, are caretakers of society and are, therefore, every bit as much ideological thinkers - although not religious ideological thinkers - as are William Dean and his type of public intellectual, who claim to espouse religion critically as a tool in the unending task of constructing and re-constructing a cohesive, common culture for the nation. Thus, although McCutcheon, as Linell Cady puts it, "does not consider professionalization and specialization the primary impediments for the scholar of religion aspiring to be a public intellectual" (Cady 1998, 36) as do other advocates for the involvement of the scholar in the public square, she is right to claim that "it does not necessarily follow that the defining characteristic of the role of the scholar of religion as public intellectual is only that of the critic, nor that the role of critic should be so sharply distinguished from that of the role of the caretaker ..." (pp. 36-37). The status quo, that is, is the status quo whether one provides a scientific account of its existence and persistence or not. And opting to oppose or to support it is an enterprise of a different kind altogether, although knowledge of how it arose and of the factors that seem still to sustain it may be of relevance to such a meta-cognitive undertaking. There is, therefore, a radical political difference between an oppositional thinking that challenges the "authorizing practices" embedded in religious systems of thought and practice from the passive (objective, non-ideological) support supposedly "lent" to such "authorizing practices" by objective scientific scholars of religion - only the oppositional thinking is ideological, and, in this respect, it is indistinguishable, except for its covert character, from that of William Dean and the others who actively espouse the authorizing practices embedded in religious thought and believe that they as scholars of religion should be in the public square, actively shaping culture and society.

It appears that McCutcheon's complaint against students of religion who "attempt to return religious commitment to public life" $(2000,167)$ is not that 
they contravene the standards of proper academic/scientific scholarship and research but rather that they espouse a religious (transcendent, supernatural, etc.) world view. He objects to the invocation of transcendent powers in what he takes to be a wholly natural world and is critical, therefore, of the scholar who "merely" describes or interprets religion in a phenomenological or hermeneutical fashion rather than "disclosing" its mythical character and making use of that disclosure to undermine its likely influence - in his judgment - on moral, social, and cultural aspects of life. ${ }^{24}$ He seems to believe that objective scientific scholarship can disclose the groundlessness (that is, the mythic character of) religious thought and practice, yet argues that the student of religion must go beyond mere objective explanation to a critique of religion because "it is our task to ask difficult questions about religion as a human institution that protects itself from critical examination" (McCutcheon 2000, 168). Indeed, if academic students of religion fail to do so, he claims, they will have nothing to say "when it comes to addressing issues of public concern" (p. 169).

\section{The Study of Religion as "scientific undertaking"}

In a review of the Jensen and Rothstein volume, Johannes Wolfart (2001) notes that there are some "'scientists' of religion" who "deride the entire concept of the public intellectual" (Wolfart 2001, 226). They do so, he claims, either because they see the notion as superfluous because a rational consideration of the facts of religion speak for themselves or because they see the notion as "a humanist trope, one which, at best, mixes scientific reasoning with moral determination and, at worst, reintroduces Christian theology [into the university context] through the back door" (pp. 226-227). I am one of those "scientists" and the arguments I have laid out here against both Dean and McCutcheon fall under these rubrics. Dean makes no bones about his desire to return religion/theology to the university and his use of the

\footnotetext{
${ }^{24}$ Given McCutcheon's position on this matter, there is a sense in which he espouses a form of what Stanley Fish calls "cognitive idealism" in that he seems to suggest that, as Fish puts it, "if we can only get our intellectual categories straight and in order, then we will be able to order, revolutionize, clean up, improve, and purify the world" (Olson 2002, 122).
} 
notion of the public intellectual is just a means to that end. McCutcheon's argument is not one in support of the return of religion to the university context; indeed, he vociferously opposes such a project. The ambiguity of his "program" for the study of religion in the context of the modern university nevertheless suggests that, structurally, his position is much like that of Dean: he too, that is, is concerned with the construction of a wholesome public order. McCutcheon, as I have argued, both claims that a purely rational consideration of the facts of religion ought to/will automatically undermine any formative role for religion in the construction of social order and, no less than Dean, he espouses a form of mythmaking (even if only implicitly so) to ground society. In the final analysis, then, McCutcheon is no more concerned for a purely scientific study of religion than are the religiously and theologically orientated students in the field whom he opposes. Like his counterpart religious public intellectuals, he wishes to employ Religious Studies to social ends, even though the modern study of religion emerged as an objective (i.e., cognitively orientated) enterprise distinct from matters of metaphysics and politics (i.e., meaning). As an academic and scientific undertaking, as Kurt Rudolph has put it, "the study of religion ought not to permit itself to propagate in any way either a religion, or theology, or an atheistic worldview" [either explicit or implicit, one might add] (Rudolph 2000, 238); for "the methods of the study of religion are bound to the same rational presuppositions that undergird any scientific study: they must be critical, analytical, objective, interpretative, explanatory, and so on" (p. 234). This puts the academic study of religion in what I will call "the public domain" (that is, in the sphere of the intersubjective testability of knowledge claims) rather than in what I have referred to above as "the public square"; that is, Religious Studies is an enterprise dedicated to providing public knowledge about public facts (in this case, of religions and religion). It is directed to cognitive ends rather than moral, social, political, economic, or other practical goals appropriate to "the public square". ${ }^{25}$ McCutcheon's call for the academic student of religion to become a public intellectual,

\footnotetext{
${ }^{25}$ See note 2 above.
} 
like Dean's, is a call for the scholar to operate in the public square, a realm in which persons engage in debate on matters of the common good - for community and country; debates that involve, explicitly or implicitly, metaphysical and ideological commitments. ${ }^{26}$ Such students of religion would simply add to the interminable disputes generated by the theologians which the scientific study of religion was designed to transcend.

Despite McCutcheon's rejection of religious commitments, and his refusal to supplant such religious commitment with an explicit alternative world

${ }^{26}$ To see how taking either of these options seriously might change radically the nature of the
discipline of Religious Studies (and its pedagogy) one need only look at the proposals for the
field by Mark D. Wood and Susan E. Henking. Wood's essay, "Religious Studies as Critical
Organic Intellectual Practice" (2001), inspired by Judith Plaskow's 1998 AAR presidential ad-
dress, presents a critique of the scientific approach to the study of religion and then proceeds
to argue a more radical proposal than that put forward by William Dean. For Wood, the
objective of Religious Studies ought to be the production of non-conformists and creatively
maladjusted citizens who will remake society rather than make "the good citizen" (Wood 2001,
152). There is nothing clearer for Wood than that the Student of religion ought to transform their
scholarship into efforts in support of "social justice, human rights, and ecological integrity"
(p. 124). For Wood, the university - and, therefore, the study of religion - must not become an
ivory tower; that is, the university campus, its libraries, classrooms, research facilities, and so
on must not become separated from life in the world, and scholars of religion must "develop
and engage in the praxis of [R]eligious [S]tudies as critical organic intellectual practice" (p.
131, emphasis added).

According to Wood, this involves not only challenging the status quo but "forging alternatives to capitalism" (2001, 133-34). And this is something that cannot be done simply by presenting world religions as nothing more "than merely more commodities for consumption in the global spiritual shopping mall ..." which in his opinion, is ultimately all that a strictly scientific approach to the study of religion permits. The religions, rather, must be presented as sets of values that contain principles of organization that challenge capitalist ethics (p. 136). Without providing a critique of "the dynamic relationships between religious life and capitalist forces", he writes, "the study and teaching of religion risks supporting the same social system that some religious communities around the world are battling to contest [in an attempt to] regain control over their own conditions of existence" (p. 138). For Wood, therefore, the classroom must concern itself not with abstract knowledge about religions and religion but rather with "emancipatory knowledge" that utilizes Gramsci's notions of "culture, hegemony, and counterhegemony" in the investigation of "the complex and dynamic relationships among religion, property, and power" (p. 138). This, he argues, will help students become "individuals who are capable of challenging corporate control of planetary life" (p. 138) and so "rid the world of ... social ills" (p. 143). He further maintains, quoting Plaskow (1999), that all religious studies scholars should bring "'religious resources to bear on important social problems"' (p. 147): "We should take up Plaskow's proposals to begin with critical analyses of sensuous labor, to make questions of economic justice and social justice central to our research and teaching, to present alternative possibilities for organizing our relations with each other and nonhuman nature, and to link theoretical knowledge to societal problems by connecting our scholarship, pedagogy, and students to local and global matters of ethical consequence. These tasks con 
view, his insistence that the commonweal depends upon the deconstruction, if not destruction, of religion shows his understanding of the task of the academic student of religion to be structurally and functionally indistinguishable from those against whom he writes. McCutcheon, no less than those he criticizes, expects scholars of religion to form a kind of clerisy. He is clearly rejecting one kind of "salvation" for society in favour of another, though more modest and mundane, proposal for achieving the good society. But like his opponents, he fuses issues of morality, meaning, and cognition, and fails to see that the modern research university, unlike its predecessors,

stitute core elements of a progressive agenda for [R]eligious [S]tudies and the humanities" (p. 147). To do this, Wood proceeds, will require giving up the "banking concept" of teaching for a more radical pedagogy that will help students find their own theological voice (p. 150). A pedagogy capable of achieving this will involve students in "building bridges between students and extra-academic organizations and agencies in order that students practice the art of engaging theoretically and practically with [what Plaskow refers to as] 'the real life problems of society'"' (p. 154). This, of course, re-creates Religious Studies into a political (institutional) force; as Wood puts it, "[i]n this way, [R]eligious [S]tudies may become a praxis that transforms social relations" (p. 154, emphasis added). Such a view of Religious Studies, therefore, means that students of religion cannot simply restrict themselves "to interpret[ing] the world in so many different religious ways" but requires them "to become critically, creatively, and compassionately engaged in the task of building a just, democratic, and humane global society" (p. 159). Religious Studies, that is, is not primarily a scientific undertaking but rather a religiously ideological formation of students aimed at equipping them to engage in the political transformation of their society. Indeed, disciplinary concerns do not even register for Wood, let alone dominate his understanding of Religious Studies as an academic enterprise.

In her article, "Who is the Public Intellectual? Identity, Marginality, and the Study of Religion" (2000), Henking argues, plausibly, that McCutcheon's stance on the Religious Studies scholar as public intellectual raises "the spectre of identity scholarship which, like identity politics, are the subject of important critique as well as of emancipatory hope" (Henking 2000, 162). Although she finds what we might call his distinction between "the religious public intellectual" and "the academic public intellectual" congenial, she nevertheless rejects the notion of a value-free academic study of religion implicit in McCutcheon's position; that is, "the binary opposition which characterizes contributions by religious studies folk as public intellectuals as either value free or crypto-theological" (pp. 162-163). Consequently, she maintains that "the hope of the field lies in its critical examination of its own 'social authorizing practices' rather than enforcement of a 'scientific' (read naive scientistic) objectivity or neutrality" ( $p$. 163). According to Henking, the "social authorizing practices" are determined by the "context" of the scholar and her/his audience (p. 163). Thus, whereas McCutcheon seems to think that neutral (naturalistic) scientists can function as public intellectuals in that they "disclose" what is hidden from view with respect to religions as "authorizing practices", Henking maintains that everyone is necessarily a public intellectual because they speak from a particular (that is, politically charged) point of view. As she puts it, it is our task to see "how our commitments to values such as feminism, antic-racist and anti-homophobic work, can best be within and beyond [R]eligious [S]tudies. In this our role is, in part, to remember that the academy itself is a public place" (p. 169). Henking does not, however, explain how the academy as public space differs from other public spaces. Nor does McCutcheon. 
is no longer directed toward the formation of the student as good citizen, but rather sees itself as a provider of objective research and scholarship; applying systematic, rational inquiry in the search for knowledge about the world. And as Tim Murphy has put it in his critical analysis of McCutcheon's position: "The scientist qua scientist need not necessarily contest the system of social representations ... because the scientist qua scientist holds to no totalizing ideology which creates a systematic opposition to any narrative or ideology" (Murphy 2000, 190).

Although Wolfart might find some agreement with my critiques of Dean and McCutcheon, he clearly will have no truck with the foundation on which my criticism of them is based. For him, the kind of "'scientists' of religion" approach to the study of religious phenomena I espouse is dogmatic and obstructive. As he puts it with respect to the contributions of Tim Murphy and Kurt Rudolph to Secular Theories on Religion - which I have invoked in support of my argument against McCutcheon - such an approach allowed them "the opportunity to rehearse well-worn statements concerning the superiority - both epistemological and, one suspects, moral - of science over religion" (Wolfart 2001, 224). Wolfart maintains that if one gives up what he calls "that tired modernization narrative according to which the post-Enlightenment period witnessed the rise of a 'secular consciousness', where secular is explicitly considered synonymous with 'profane'" (p. 224), one would not have to give up the notion of the public intellectual in favour of a scientific study of religion, or presume the public intellectual to be a public pedagogue who "speak[s] for the public on the basis of superior knowledge" (p. 227). The student of religion who refuses to reify the secular, and who recognizes the secular for what it is - namely, the discovery of historicity itself - he claims, can be responsive and responsible to the people with whom s/he lives in the public square (p. 227).This, he tells us, is what secularism means for the scholar of religion who would be a public intellectual. It makes possible a "secular responsibility" not because it is irreligious but because it relates to temporal (historically specific) social and political concerns. Wolfart therefore believes an alternative model for 
the student of religion as public intellectual to those provided by the likes of Dean and McCutcheon is available. He writes: "There is the possibility of a public intellectual who is neither didactic nor apologetic but is, rather, prepared to converse with a public from a position within that public; in other words, one that neither tells the public what to do or think, nor seeks public authorization or approval" (p. 227, emphasis added).

This "solution" to the problem of the academic in the public realm, however, is in my judgment incoherent for it erases all distinction between the scholar/academic and the ordinary man or woman in the public square; as Wolfart himself puts it: "I see no meaningful distinction between an academic priesthood and an academic priesthood of all believers" (Wolfart 2001, 227). But this, of course, ignores the difference between the cognitive and epistemic concerns that characterizes the field of Religious Studies and the academic student of religion, and the social and political concerns of ordinary citizens. Erasing that difference, in my judgment, does not create an "academic priesthood of all believers" but rather simply subordinates the academic agenda to that of the public square. That, however, may well be the agenda of the authors included in Secular Theories of Religion to whom Wolfart is attracted, but it is not the epistemic (scientific) one espoused by the modern research university to which I am committed; it is, indeed, rather an ideological and political goal directed to subverting that institution. Thus, like Wolfart, I also raise the question as to whether there are other models that open the public square to the academic. And I suggest that recognizing that scholars and scientists are more than simply scholars and scientists makes possible a different kind of interaction between them and the public square than the one he envisages, and that it does so at far less cost to the fabric of the social structures and institutions on which our society depends.

\section{Conclusion}

The academic student of religion qua human being, as I have just noted, is more than merely a scholar/scientist; s/he is also a citizen with socio-politi- 
cal, economic, and other personal concerns that go beyond science and the agenda of the modern research university, and there is no reason why s/he should not, as an ordinary citizen, engage in the debates related to such concerns in the public square. Moreover, the scholarly/scientific expertise of the engaged academic may even have some instrumental relevance to the achievement of particular social goals, even if those goals involve metaphysical and/or religious assumptions, beliefs, and commitments. Applying knowledge in such an instrumental fashion does not, however, make such persons public intellectuals; it leaves them as citizens with "public square" concerns. To become a public intellectual, as I have defined it above (see note 3), would require them to forego continued specialization in the field of Religious Studies so as to give them greater latitude of research; that is, they would have to become generalist who could reach a broad, educated public on a wide range of issues. As William Dean points out, this means that they would have to be more concerned to contribute to society in general than to the improvement and development of the discipline of Religious Studies. But if that is the case, then it would seem that it is best for those who wish to be public intellectuals - whether in the "religious critic" sense spelled out by Dean and his like, or in the "critic of religion" sense spelled out by McCutcheon and others - that they function not within departments of Religious Studies but rather, as Dean recommends (even if reluctantly), in third sector institutions other than the university. (The same, of course, would hold for Wolfart's "academic priesthood of all believers".) Such third sector institutions are also appropriate venues for the "public square" concerns of the religious studies scholar qua citizen as well. To try to "rehabilitate" the colleges and university departments of Religious Studies so as to include such social, political, and religious activities - as Dean explicitly proposes and McCutcheon and Wolfart implicitly so - will devalue the cognitive objectives of the modern university and will undermine it as an institution dedicated to rational inquiry in search for public knowledge of public facts. 
Bibliography

\section{Brown, Donald E.}

1988 Hierarchy, History, and Human Consciousness: The Social Origins of Historical Consciousness. Tucson: The University of Arizona Press.

\section{Cady, Linell}

1993 Religion, Theology, and American Public Life. Albany: SUNY

1998 The Public Intellectual and Effective Critique. - Council of Societies for the Study of Religion Bulletin 27(2), 36-38.

Cady, Linell \& Delwin Brown (eds)

2002 Religious Studies, Theology, and the University: Conflicting Maps, Changing Terrains. Albany: SUNY.

\section{Carter, Stephen}

1993 The Critique of Disbelief: How American Law and Politics Trivialize Religious Devotion. New York: Basic Books.

2001 God's Name in Vain: The Wrongs and Rights of Religion in Politics. New York: Basic Books.

\section{Clebsch, William A.}

1981 Apples, Oranges, and Manna: Comparative Religion Revisited. - Journal of the American Academy of Religion 49(1), 3-22.

\section{Dean, William}

1994 The Religious Critic in American Culture. Albany: SUNY.

\section{Eagleton, Terry}

1992 The Significance of Theory. Oxford: Blackwell Publishers.

\section{Fish, Stanley}

2004 Why We Built the Ivory Tower. - New York Times, 21 May, 2004, Section A, 23, Column 1.

\section{Gellner, Ernest}

1973 The Savage and the Modern Mind. - Robin Horton \& Ruth Finnegan (eds), Modes of Thought: Essays on Thinking in Western and Non-Western Societies, 162-181. London: Faber and Faber.

\section{Griffiths, Paul J.}

1998 Some Confusions About Critical Intelligence: A Response to Russell T. McCutcheon. - Journal of the American Academy of Religion 66(4), 893-895.

\section{Henking, Susan E.}

2000 Who is the Public Intellecual? Identity, Marginality, and the Study of Religion. - Journal of the Faculty of Religious Studies, McGill University 28, 159-171. 


\section{Holbrook, Clyde}

1964 Why an Academy of Religion? - The Journal of Bible and Religion 32(2), 97-105.

Jensen, Tim \& Mikael Rothstein (eds)

2000 Secular Theories on Religion: Current Perspectives. Copenhagen: Museum Tusculanum Press.

\section{Lincoln, Bruce}

1996 Theses on Method. - Method and Theory in the Study of Religion 8, 225-227.

Mali, Joseph

2003 Mythistory: The Making of a Modern Historiography. Chicago: University of Chicago Press.

McCaughey, Robert A.

1984 International Studies and Academic Emterprise: A Chapter in the Enclosure of American Learning. New York: Columbia University Press.

\section{McCutcheon, Russell T.}

1997 A Default of Critical Intelligence? The Scholar of Religion as Public Intellectual. - Journal of the American Academy of Religion 65(2), 443-468.

1998 Talking Past Each Other - Public Intellectuals Revisited: Rejoinder to Paul J. Griffiths and June O'Connor. - Journal of the American Academy of Religion 66(4), 911-917.

2000 Critics Not Caretakers: The Scholar of Religion as Public Intellectual. - Tim Jensen \& Mikael Rothstein (eds), Secular Theories on Religion: Current Perspectives, 167-181. Copenhagen: Museum Tusculanum.

2002 The Study of Religion as an Anthropology of Credibility. - Linell Cady \& Delwin Brown (eds), Religious Studies, Theology, and the University: Conflicting Maps, Changing Terrains, 13-30. Albany: SUNY.

McLelland, Joseph C.

1972 The Teacher of Religion: Professor or Guru? - Studies in Religion 2(3), 226-234.

McNeill, William $\mathrm{H}$.

1986a Mythistory, or Truth, Myth, History, and Historians. - William McNeill, Mythistory and Other Essays, 3-22. Chicago: University of Chicago Press.

1986b The Care and Repair of Myths. - William McNeill, Mythistory and Other Essays, 23-42. Chicago: University of Chicago Press.

\section{Michaelson, Robert}

1972 The Engaged Observer: Portrait of a Professor of Religion. - Journal of the American Academy of Religion 40(4), 419-424. 
Miles, Jack

1999 Three Differences Between an Academic and an Intellectual: What Happens to the Liberal Arts When They are Kicked Off Campus? - Cross Currents 49(3), 303-318.

Munz, Peter

1985 Knowledge of the Growth of Knowledge: Popper or Wittgenstein? London: Routledge and Kegan Paul.

Murphy, Tim

2000 Speaking Different Languages: Religion and the Study of Religion. - Tim Jensen \& Mikael Rothstein (eds), Secular Theories on Religion: Current Perspectives, 183-192. Copenhagen: Museum Tusculanum.

\section{Neuhaus, Richard John}

1984 The Naked Public Square: Religion and Democracy in America. Grand Rapids: William B. Eerdmans Publishing Company.

\section{O'Conner, June}

1998 The Scholar of Religion as Public Intellectual: Expanding Critical Intelligence. - Journal of the American Academy of Religion 66(4), 897-907.

Olson, Gary A.

2002 Justifying Belief: Stanley Fish and the Work of Rhetoric. Albany: SUNY.

\section{Plaskow, Judith}

1999 The Academy as Real Life: New Participants and Paradigms. - Journal of the American Academy of Religion 67, 521-538.

\section{Raschke, Carl A.}

1986 Religious Studies and the Default of Critical Intelligence. - Journal of the American Academy of Religion 54(1), 131-138.

\section{Rudolph, Kurt}

2000 Some Reflections on Approaches and Methodologies in the Study of Religion. - Tim Jensen and Michael Rothstein (eds), Secular Theories on Religion on Religion: Current Perspective, 231-247. Copenhagen: Museum Tusculanum.

\section{Smith, R. V. (with Dwight Beck \& Harry M. Buck \& Robert Eccles \& Clyde} Holbrook \& Leo H. Phillips)

1964 Report on the NABI Self-Study Committee. - Journal of Bible and Religion 32, 200-201.

\section{Welch, Claude}

1971 Identity Crisis in the Study of Religion? A First Report from the ACLS Study. - Journal of the American Academy of Religion, 39(1), 3-18.

Wiebe, Donald

1989 History or Mythistory in the Study of Religion? - Michael Pye (ed.), 
Marburg Revisited: Institutions and Strategies in the Study of Religion, 31-46. Marburg: Diagonal Verlag.

1998 The Politics of Religious Studies: The Continuing Conflict With Theology in the University. New York: St. Martin's Press.

2000a Why the Academic Study of Religion? Motive and Method in the Study of Religion. - Tim Jensen \& Michael Rothstein (eds), Secular Theories on Religion: Current Perspectives, 261-279. Copenhagen: Museum Tusculanum.

2000b American Influence on the Shape of Things to Come: Religious Studies in the Twenty-First Century. - Journal of the Korean Association for the History of Religions, 20(1), 1-24.

2001 Religion Thick and Thin: On the Development of "Religious'Studies" in the American University. - Reviews in Religion and Theology, 8, 334-351.

Wolfart, Johannes, C.

2001 Secular Responsibility and the Public Intellectual in the Study of Religion. - Studies in Religion, 30(2), 223-229.

\section{Wolin, Richard}

2004 The Seduction of Unreason: The Intellectual Romance in the Study of Religion. Princeton: Princeton University Press.

Wood, Mark D.

2001 Religious Studies as Critical Organic Intellectual Practice. - Journal Of the American Academy of Religion, 69(1), 129-162.

Zammito, John $\mathbf{H}$.

2004 A Nice Derangement of Epistemes: Post-Positivism in the Study of Science from Quine to Latour. Chicago: University of Chicago Press. 